\title{
触 New Disease Reports \\ First report of leaf blight and twig dieback caused by Mycoleptodiscus indicus on Ixora coccinea
}

\author{
A. Banerjee*, R. Mandal and P.S. Nath
}

Department of Plant Pathology, Bidhan Chandra Krishi Viswavidyalaya, Nadia-741252, West Bengal, India

*E-mail: arghyabanerjee18@gmail.com

Received: 21 Jun 2018. Published: 04 Aug 2018. Keywords: endophytes, ITS-rDNA, pathogenicity, sporodochia

Ixora coccinea (Rubiaceae), native to Eastern India is widely cultivated as an ornamental shrub and because its flowers, leaves, roots and stems contain phytochemicals with medicinal properties. In December, 2017, a severe foliar blight and twig dieback was observed in the gardens of Bidhan Chandra Krishi Viswavidyalaya, West Bengal. Disease incidence was up to $100 \%$ in some areas. Initial symptoms included small, reddish-brown lesions (Fig. 1a) on the leaf tip and leaf margin. Sporodochia were prevalent on both lower and upper leaf surfaces and occured singly and in clusters (Fig. 1b). The initial reddish-brown lesions enlarged and coalesced into large necrotic areas (Fig. 1c) giving rise to severe dieback due to abscission of infected leaves and flowers. (Fig. 1d). Great numbers of dark brown to black sporodochia were produced on necrotic leaf tissues. Under favourable conditions masses of hyaline, aseptate conidia were produced by conidiogenous cells.

Infected leaf and twig samples were surface sterilised with $1.5 \%$ sodium hypochlorite for two minutes, plated on $2 \%(\mathrm{w} / \mathrm{v})$ potato dextrose agar amended with chloramphenicol $(0.5 \mathrm{mg} / \mathrm{l})$ and incubated at $25^{\circ} \mathrm{C}$ under a $12 \mathrm{hr} / 12 \mathrm{hr}$ light/dark cycle for seven days. Fungal growth from the material was cream coloured but yellowish when viewed from beneath (Fig. 2). Hyphae were septate, branched, brown to dark brown and 3-7.5 $\mu \mathrm{m}$ wide, and formed many clypeate, dark brown sporodochia consisting of compressed phialides which were ampulliform to doliiform or irregular in shape. The number of conidiogenous cells in a sporodochium varied widely and many sporodochia failed to produce conidia. The conidiogenous cells showed non-pigmented, circular, phialidic apertures. Conidia were few and were hyaline, aseptate, often guttulate and curved, with an apical setula measuring up to $3 \mu \mathrm{m}$ long but rarely with a basal setula. Conidia $(\mathrm{n}=50)$ measured $10-16 \mu \mathrm{m} \times 4.5-7.0 \mu \mathrm{m}$. On the basis of conidial and cultural characteristics, the fungus was identified as Mycoleptodiscus indicus (Sutton, 1973; Sutton \& Hodges, 1976). The identification was confirmed by molecular analysis of the $5.8 \mathrm{~S}$ subunit and flanking internal transcribed spacers (ITS1 and ITS2) of rDNA amplified from DNA extracted from single-spore cultures with the ITS1/ITS4 primers (White et al., 1990) and sequencing. The sequence obtained from present study (GenBank Accession No. MH479058) showed 99\% identity with Mycoleptodiscus indicus isolate JSP05-02C3.1 (KR093950). onto five needle-pricked young leaves and twigs; comparable inoculations were done with sterile water as a control. The procedure was repeated five times and inoculated plants were maintained in a controlled environment $\left(25^{\circ} \mathrm{C}, 80-85 \%\right.$ humidity with a $12 \mathrm{hr}$ photoperiod). After $12-15$ days all the inoculated leaves developed necrotic symptoms (Fig. 3a) similar to those observed on naturally infected leaves, whereas control leaves remained symptomless. Twig dieback symptoms developed ten days after inoculation (Fig. 3b). Re-isolation from the inoculated leaves and twigs consistently yielded $M$. indicus.

Mycoleptodiscus indicus has previously been recorded as a plant pathogen (Ostazeski, 1967; Alfieri et al., 1984; El-Gholl \& Alfieri, 1991) but to the best of our knowledge, this is the first report of disease on I. coccinea caused by $M$. indicus.

\section{References}

Alfieri Jr SA, Langdon KR, Wehlburg C, Kimbrough JW, 1984. Index of plant diseases in Florida. Florida Department of Agriculture and Consumer Services, Division of Plant Industry Bulletin 11, 1-389.

El-Gholl NE, Alfieri Jr SA, 1991. Leaf necrosis of Zamia caused by Mycoleptodiscus indicus. Florida Department of Agriculture and Consumer Services, Division of Plant Industry, Plant Pathology Circular 349.

Ostazeski SA, 1967. An undescribed fungus associated with a root and crown rot of birdsfoot trefoil (Lotus corniculatus). Mycologia 59, 970-975. http://dx.doi.org/10.2307/3757270

Sutton BC, 1973.Pucciniopsis, Mycoleptodiscus and Amerodiscosiella. Transactions of the British Mycological Society $\mathbf{6 0}$, 525-536. http://dx.doi.org/10.1016/S0007-1536(73)80036-1

Sutton BC, Hodges CSJ, 1976. Eucalyptus microfungi:

Mycoleptodiscus species and Pseudotracylla gen. nov. Nova Hedwigia $\mathbf{2 7}$, 693-700.

White TJ, Bruns T, Lee S, Taylor JW, 1990. Amplification and direct sequencing of fungal ribosomal RNA genes for phylogenetics. In: Innis MA, Gelfand DH, Sninsky JJ, White TJ, eds. PCR Protocols: A Guide to Methods and Applications. New York, USA: Academic Press Inc., 315-322.

Pathogenicity was tested by spraying a conidial suspension $\left(1 \times 10^{6} / \mathrm{ml}\right)$
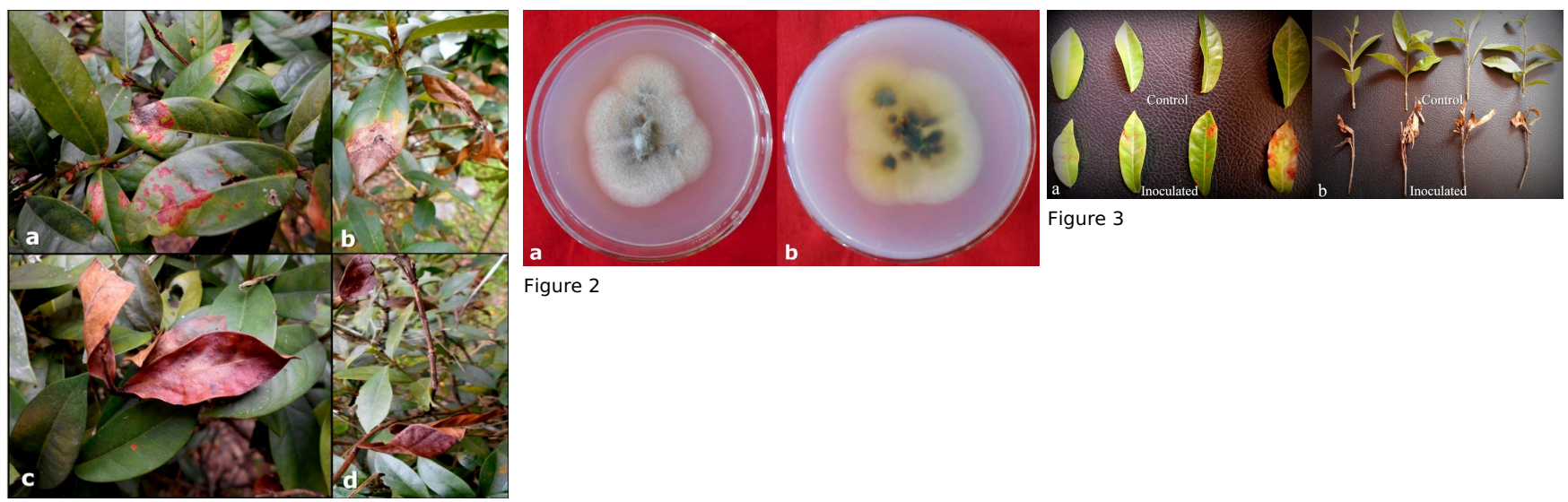

Figure 2

Figure 1

To cite this report: Banerjee A, Mandal R, Nath PS, 2018. First report of leaf blight and twig dieback caused by Mycoleptodiscus indicus on Ixora coccinea. New Disease Reports 38, 5. http://dx.doi.org/10.5197/j.2044-0588.2018.038.005

(c) 2018 The Authors

This report was published on-line at www.ndrs.org.uk where high quality versions of the figures can be found. 